PSYCHOLOGIA ROZWOJOWA, $2020 *$ tom 25 , nr 4, s. $113-116$

doi:10.4467/20843879PR.20.031.13924

www.ejournals.eu/Psychologia-Rozwojowa

MARIA KIELAR-TURSKA ๑i https://orcid.org/0000-0002-6543-7030

Instytut Psychologii, Akademia Ignatianum w Krakowie Institute of Psychology, Jesuit University Ignatianum in Krakow e-mail: maria.kielar-turska@ignatianum.edu.pl

\title{
Jubileusz Profesor Idy Kurcz
}

W dniu 14 września 2020 roku na Wydziale Psychologii Uniwersytetu Warszawskiego obchodzono 90-lecie niezwykle twórczego, bogatego w naukowe osiągnięcia życia Profesor Idy Kurcz. Spotkanie, w którym uczestniczyło wiele osób z ośrodków naukowych z całego kraju, zaprojektowała i elegancko prowadziła Profesor Barbara Bokus.

Spotkanie to, podobnie jak wiele innych organizowanych w okresie pandemii, odbyło się w formie na odległość, na platformie przeznaczonej do kontaktów online. Zamieszczona w tekście fotografia pochodzi z tego spotkania. I choć nie można było przywitać się uściskiem dłoni, to serdeczne, czułe słowa tworzyły atmosferę bliskości. Były też kwiaty dla Jubilatki wręczone Jej bezpośrednio przez ,naukową wnuczkę" Kingę Wojaczek wraz z gratulacjami i podziękowaniami ,za wszystko, czego się nauczyliśmy".

Uroczyste spotkanie z Jubilatką rozpoczęło się prezentacją jej naukowych osiągnięć. Ida Kurcz urodziła się 13 września 1930 roku w Łodzi, gdzie zdobywała podstawową wiedzę o świecie w Liceum Humanistycznym im. Hoffmanowej. Podjęła studia psychologiczne na Uniwersytecie Warszawskim w 1949 roku i otrzymała dyplom w 1954 roku, doznając podczas studiów charakterystycznych dla tamtych czasów skutków rozwiązań trudnych (np. zamknięcie kierunków ideologicznych, takich jak psychologia) i nietypowych (będąc studentką trzeciego roku, została zastępcą asystenta). Cała droga naukowa Profesor Idy Kurcz jest związa-

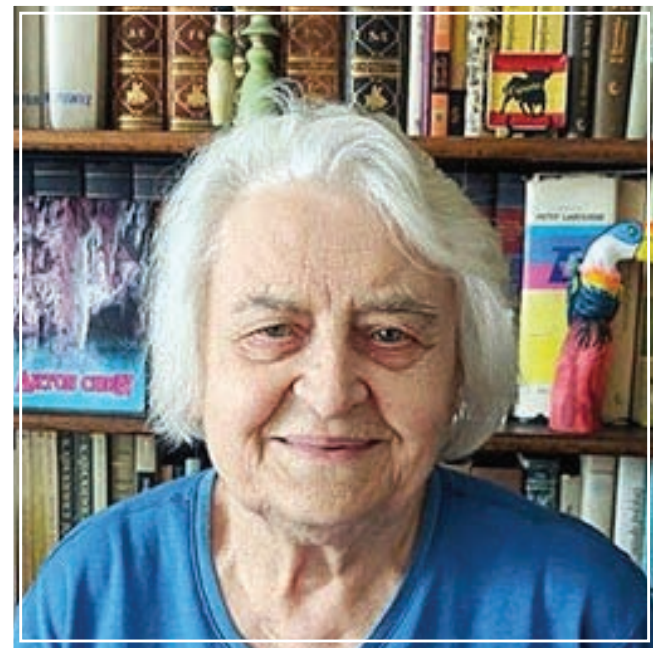

na z Uniwersytetem Warszawskim, na którym zdobywała kolejne stopnie naukowe i pełniła różne ważne funkcje (kierownika: Zakładu Podstaw Psychologii, Zakładu Psychologii i Kształcenia Nauczycieli, Pracowni Psycholingwistyki, Katedry Psychologii Poznawczej; zastępcy dyrektora Instytutu Psychologii). Największy podziw i uznanie budzi jej dorobek naukowy utrwalony w formie tekstów książek autorskich, współautorskich czy przygotowywanych pod jej redakcją. Wszystkie prace dotyczą psychologii poznania i psychologii języka.

Opublikowana w 1992 roku praca Pamięć, uczenie się, język była podstawowym podręcznikiem do studiów nad procesami poznawczymi, ukazującym historię badań, metodykę badania procesów poznawczych i dotychczasowe od- 
krycia. Nadal stanowi ważne opracowanie dla studentów i badaczy rozpoczynających swoje poszukujące studia nad wyjaśnianiem procesów poznawczych. O tej pracy wspominał podczas spotkania prof. Przemysław Bąbel (UJ), zaznaczając wyjątkowe jej znaczenie w swoich studiach psychologicznych.

Jako uczennica i asystentka Profesora Tadeusza Tomaszewskiego Ida Kurcz przyczyniła się do propagowania jego teorii czynności, przygotowując jako współredaktor następujące pozycje: Studia nad teoria czynności ludzkich (1975, wspólnie z prof. Januszem Reykowskim) oraz Psychologia czynności (2002, wspólnie z prof. Danutą Kądzielawą).

Najwięcej opracowań Profesor Idy Kurcz dotyczy psychologii języka. Swoimi pracami zainicjowała w Polsce myślenie o nowym nurcie badań nad językiem - psycholingwistyce. W Polsce prowadzone były badania nad językiem, zwłaszcza nad procesem opanowywania języka, zaprojektowane przez Profesora Stefana Szumana, korzystające w znacznym stopniu z osiągnięć językoznawstwa. Powstanie psycholingwistyki w latach pięćdziesiątych w USA przyczyniło się do nowego spojrzenia na język i na proces jego nabywania, odkrywając mechanizmy wyjaśniające ten proces. Zarówno temat pracy magisterskiej (1954, O dwojakiej funkcji słowa jako bodźca), jak i pracy doktorskiej (1962, Generalizacja semantyczna ruchów dowolnych) ujawniają wczesne zainteresowanie Idy Kurcz zagadnieniami związanymi z posługiwaniem się językiem. Najważniejszą była monografia Psycholingwistyka (1976), opublikowana przez Państwowe Wydawnictwo Naukowe, w serii Biblioteka Psychologii Współczesnej. Praca ta pokazywała źródła powstania nowej dziedziny wiedzy, wzbudzając jednocześnie refleksję nad charakterystyczną dla ostatniego ćwierćwiecza cechą przemian w nauce wyrażającą się integrowaniem nauk, wzajemnym korzystaniem z wypracowanych modeli. Okazało się, że modele informatyczne czy językoznawcze zastosowane w badaniach nad językiem pozwalają zgłębić jego strukturę, odkryć różne funkcje języka, a także wyjaśnić proces jego nabywania. $Z$ kolei wiedza o procesach poznawczych i ich mechanizmach pozwalała wyjaśniać proces powstawania znaczeń i tworzenia obrazu świata z użyciem języka. Profesor Kurcz z zainteresowaniem śledziła ukazujące się za granicą prace z zakresu psycholingwistyki; aktywnie uczestniczyła również w międzynarodowych konferencjach poświęconych tej problematyce. W swoich kolejnych publikacjach omawiała pojawiające się nowe koncepcje i wyniki badań empirycznych, opatrując je efektami swych przemyśleń. Wszystkie prace Idy Kurcz z zakresu psychologii poznania i psycholingwistyki stanowią podstawowe, rzetelne źródło informacji.

Warto zwrócić uwagę na prowadzone wspólnie z Anną Polkowską badania nad przetwarzaniem informacji językowych (Interakcyjne $i$ autonomiczne przetwarzanie informacji językowych, 1990), które odkryły charakterystyczne cechy tekstów łatwych i trudnych do dekodowania. Okazało się, że łatwe do zrozumienia są teksty narracyjne, składające się z prostych, krótkich zdań zbudowanych z krótkich słów, zawierające niewiele słów abstrakcyjnych i niewiele zdań przeczących. Wspomniana praca, jak i rozważania nad reprezentacją poznawczą (Język a reprezentacja świata $w$ umyśle, 1987) były dla mnie, autorki tego sprawozdania, inspiracją do badań nad rozwojem reprezentacji poznawczej różnych wycinków wiedzy, takich jak wolność, polityka, norma i inne.

Ważnym kierunkiem aktywności naukowej Idy Kurcz było organizowanie spotkań osób zainteresowanych zagadnieniami psycholingwistycznymi. Od 1970 roku odbywały się Sympozja Psycholingwistyczne, na których prezentowane były badania polskich, a także zagranicznych badaczy połączone z dyskusjami. Współpraca z innymi ośrodkami naukowymi w Polsce sprzyjała organizowaniu takich dyskusyjnych sympozjów w różnych miejscach w kraju; jedno z nich odbyło się w Krakowie w 1973 roku we współpracy z Profesor Marią Przetacznik-Gierowską. Dzięki aktywnemu zaangażowaniu Idy Kurcz w propagowanie zagadnień z zakresu psycholingwistyki wiele młodych osób zainteresowało się tą nową dziedziną wiedzy. Nie tylko studiowali literaturę, ale także prowadzili badania, uczestniczyli w kon- 
ferencjach naukowych, zarówno polskich, jak i zagranicznych.

Zainteresowanie środowiska polskich naukowców psycholingwistyką i jej związkiem z różnymi dziedzinami wiedzy znalazło wyraz w zorganizowanym przez Profesora Adama Schaffa w latach 1976-1980 konwersatorium z filozofii języka w Polskiej Akademii Nauk w Warszawie. W dyskusjach na tym konwersatorium ważny był głos Idy Kurcz. W spotkaniu uczestniczyli badacze języka prezentujący różne dyscypliny naukowe, między innymi: językoznawcy (Halina Mierzejewska, Waldemar Tłokiński, Bronisław Rocławski), socjolodzy (Marek Ziółkowski, Andrzej Piotrowski), filozofowie (Jerzy Pelc, Józef Niżnik), psychologowie (Grace Shugar, Barbara Bokus, Danuta Kądzielawa, Maria Przetacznik-Gierowska, Maria Kielar-Turska).

Profesor Ida Kurcz nie tylko dostarczała informacji z zakresu nowej dyscypliny wiedzy, jaką jest psycholingwistyka, ale także podejmowała działania zmierzające do umożliwienia wymiany myśli i prezentacji wyników badań prowadzonych w Polsce. W sposobie uprawiania nauki przez Idę Kurcz wyraźnie zaznaczała się idea dzielenia się efektami naukowych poszukiwań.

Wypowiedzi i listy gratulacyjne kierowane pod adresem Jubilatki złożyły się na obraz osoby niezależnej, niezwykle rzetelnej w pracy, bogatej w doświadczenia naukowe, aktywnie oddziałującej na osoby w swoim środowisku.

Profesor Janusz Reykowski w odczytanym na uroczystości liście wspominał okres wspólnej z Idą Kurcz asystentury i współpracy naukowej w Instytucie Psychologii. Mówił, że życie Idy Kurcz postrzega jako bogate w doświadczenia z ważnym osiągnięciem, jakim było stworzenie w Polsce nowej dyscypliny naukowej - psycholingwistyki. Zdaniem Reykowskiego studia Idy Kurcz w zakresie psycholingwistyki oraz międzynarodowa współpraca przyniosły jej uznanie w kraju i za granicą.

Rektorzy i Dziekani polskich uniwersytetów oraz dyrektorzy Instytutów Psychologii $\mathrm{z}$ różnych uczelni w kraju składali Jubilatce gratulacje i życzenia sił twórczych oraz zdrowia. Dziękowali także za możliwość korzy- stania z osiągnięć nauki polskiej i światowej poprzez jej publikacje. Zaznaczano, że książki Idy Kurcz należą do kanonu lektur humanisty; poprzez swoją działalność naukową wniosła Ona osobisty wkład w kulturę. W listach i bezpośrednich wypowiedziach wyrażano uznanie, szacunek i podziw dla Jubilatki za jej naukowe osiągnięcia, a także podziękowania za osobiste kontakty, za życzliwość i wyrozumiałość. Podkreślano, że Jubilatka jako naukowiec stanowi wzorzec, do którego się dąży.

Profesor Ida Kurcz jest, zdaniem prof. Jerzego Bralczyka, ważną postacią w życiu naukowym. Jej zasługę stanowi połączenie ujmowania języka z inną niż językoznawcza perspektywą badawczą - psychologiczną. Profesor Bralczyk jako językoznawca, felietonista nadal korzysta z tej wiedzy; ma zaszczyt, że mógł być jej kolegą.

O znaczeniu naukowej działalności Jubilatki dla logopedii mówił prof. Stanisław Grabias. Przypomniał działania Idy Kurcz w Komisji Rozwoju i Zaburzeń Mowy Polskiej Akademii Nauk. Ida Kurcz domagała się uwzględnienia w badaniach nad językiem tego, jak ludzie mówią, wskazując na indywidualny wymiar ludzkiej komunikacji.

Były także podziękowania od Polskiego Towarzystwa Psychologicznego (dr Małgorzata Toeplitz-Winiewska, mgr Teresa Pawlas) oraz Fundacji na Rzecz Rozwoju Psychologii im. Tadeusza Tomaszewskiego (prof. Zofia Ratajczak) za dawanie siebie i swoich naukowych talentów innym, za nowatorstwo i reprezentowanie polskiej psychologii w międzynarodowych gremiach.

Były także gratulacje i podziękowania ze strony redaktorów czasopism i wydawnictw naukowych. Redaktor Polish Psychological Bulletin, prof. Dariusz Doliński, gratulował Jubilatce intelektualnej formy, dziękując za prace na rzecz czasopisma w roli członka zespołu redakcyjnego i autora. Z kolei redaktorka Psychology of Language and Communication, prof. Joanna Rączaszek-Leonardi, zwracała uwagę na to, że czasopismo integruje naukę wschodnią i zachodnią, przedstawia różne zagadnienia, łączy dotykanie ludzkiego doświadczenia z językiem. Wszystko to ma swoje źródło w psycholingwi- 
styce rozwijanej w Polsce przez Jubilatkę oraz w jej otwartości i dążeniu do współpracy.

Redaktorzy wydawnictw (PWN, Scholar, GWP), składając Jubilatce życzenia zadowolenia z pięknie przeżytego życia, uważali wydawanie prac Idy Kurcz za wyróżnienie, bowiem ich zdaniem jest Ona postacią pomnikową w nauce, a jej teksty odznaczają się precyzją myśli i logiką wywodu.

Jubilatce gratulowali i dziękowali Jej uczniowie i współpracownicy z Katedry Psychologii Poznawczej i Neurolingwistyki Uniwersytetu Warszawskiego. Podkreślano imponujący dorobek naukowy oraz dydaktyczny Jubilatki i prekursorstwo w zakresie psycholingwistyki w Polsce. Zwracano uwagę na miły sposób kontaktowania się z innymi oraz składano życzenia, aby wysiłki Idy Kurcz mogły owocować w kolejnych pokoleniach.

Nie zabrakło także słów wzruszenia, podziwu i dumy ze strony rodziny Jubilatki, rozproszonej po całym świecie. Dumny z babci telefonował wnuk z Nowego Jorku, Adam Piesowicz, a syn, Paweł Piesowicz z Toronto, był przy Niej obecny.
Jubilatka Profesor Ida Kurcz była wzruszona. Uważa, że psycholingwistyka urozmaiciła jej życie, była okazją do zaprzyjaźnienia się $\mathrm{z}$ wieloma naukowcami z całego świata. Jednakże zaznaczyła, że jej radość została zaprawiona smutkiem $\mathrm{z}$ powodu choroby prof. Janusza Reykowskiego, z którym przyjaźniła się 70 lat, oraz z powodu żałoby po odejściu w ostatnich tygodniach kilku profesorów psychologii.

Muzycznym ozdobnikiem jubileuszowego spotkania był występ Chóru Uniwersyteckiego, który wykonał pieśni Stanisława Moniuszki, a na zakończenie odśpiewał piosenkę Czerwony autobus. Piosenkę tę, ze słowami Andrzeja Boguckiego, wykonywał w latach sześćdziesiątych Chór Czejanda, dając poczucie nowości, odrodzenia i inspirując aktywność. Taką inspirację naukową zawierały prace Idy Kurcz, które nadal aktywizują nowych adeptów nauki. Cytując słowa piosenki: „Wszyscy patrzą, jakby pierwszy raz zobaczyli miasto swe" - można powiedzieć tak o inspirującej roli i znaczeniu naukowego dorobku Jubilatki, Profesor Idy Kurcz. 